\title{
Canto de Amor à Faculdade*.
}

\author{
Paulo Bomfim \\ Da Academia Paulista de Letras
}

\author{
Somos passado e futuro, \\ Presente de indagações, \\ Pedra de sonhos crescendo \\ No Largo de São Francisco; \\ Canção de velhas violas \\ Embalando cosmonautas, \\ Arcadas que o tempo arcou \\ Para que delas partissem \\ Flechas de amor e protesto, \\ Setas com plumas de dor \\ $\mathrm{E}$ pontas de inconformismo. \\ - Em vossos olhos o olhar \\ Das gerações que partiram, \\ Das gerações que virão. \\ Em vossa luz a palavra \\ Estrela de tanta noite! \\ Em vossas mãos a bandeira \\ Bordada por vossos mortos, \\ Bandeira que é céu de Pátria, \\ Terra prenhe de esperança, \\ Canção de guerra e de paz \\ $\mathrm{Na}$ audácia de vossas lanças! \\ - Pela memória da terra, \\ Pelos segredos do Pátio, \\ Pela prece das Arcadas, \\ Pela aurora das paredes, \\ Pelo mistério das salas,
}

\footnotetext{
* Poesia declamada na sessão solene de abertura dos festejos comemorativos do sesquicentenário de fundação dos Cursos Jurídicos no Basil, realizada no salão nobre desta Faculdade, a 11 de agosto de 1976.
} 
Pelo grito das estátuas,

Pela voz da escadaria,

Pela clareira do Largo,

Pela bênção das telhados,

Pela alma dos poetas,

Pelo martírio de heróis,

Por tudo que é São Francisco,

Por tudo que é mocidade,

Seja nossa vossa causa,

Seja vossa nossa luta,

$\mathrm{E}$ por paixão; rebeldia,

Sede de amor, de justiça,

Viva em nós a rosa agreste

$\mathrm{E}$ escreva com seus espinhos

$\mathrm{E}$ grave com nosso sangue,

Em muros, mares e ventos

A palavra - Liberdade!

São Paulo, 20 de julho de 1976. 